\title{
Effect of Momordica charantia protein on proliferation, apoptosis and the AKT signal transduction pathway in the human endometrial carcinoma Ishikawa $\mathrm{H}$ cell line in vitro
}

\author{
HANG-ZHI GU* , RONG-RONG LIN*, HAN-CHU WANG, XUE-JIE ZHU, YAN HU and FEI-YUN ZHENG
}

Department of Gynecology, The First Affiliated Hospital of

Wenzhou Medical University, Wenzhou, Zhejiang 325000, P.R. China

Received August 3, 2015; Accepted November 17, 2016

DOI: $10.3892 / \mathrm{ol} .2017 .5830$

\begin{abstract}
Endometrial carcinoma (EC) is one of the most common female malignancies, and there is an urgent requirement to explore new therapeutic strategies. In the present study, Ishikawa H cells were treated with Momordica charantia protein (MCP30). The cell morphology, growth inhibition rate, cell cycle distribution, and expression of phosphate and tensin homolog, P-AKT and AKT were measured. DNA fragmentation analysis and Annexin V-fluorescein isothiocyanate/propidium iodide double staining assay were used to analyze cell apoptosis. MCP30 decreased the viability of Ishikawa $\mathrm{H}$ cells in a dose- and time-dependent manner. The early apoptotic rates of Ishikawa $\mathrm{H}$ cells treated with MCP30 at $666.67 \mathrm{pM}$ reached to $16.07 \pm 0.15 \%$, following $72 \mathrm{~h}$ of treatment. DNA ladder was observed in cells treated with 333.33 and $666.67 \mathrm{pM}$ MCP30 following $72 \mathrm{~h}$ of treatment. MCP30 blocks Ishikawa $\mathrm{H}$ cells from progressing between the S-phase and the G2/M-phase in a time- and concentration-dependent manner. Western blotting revealed that MCP30 treatment decreased the levels of P-AKT in a dose-dependent manner. It was revealed that $\mathrm{MCP} 30$ decreases cell proliferation, and induces apoptosis and S-phase cell cycle arrest through the AKT signaling pathway in Ishikawa $\mathrm{H}$ cells.
\end{abstract}

Correspondence to: Professor Fei-Yun Zheng, Department of Gynecology, The First Affiliated Hospital of Wenzhou Medical University, South Baixiang Street, Wenzhou, Zhejiang 325000, P.R. China

E-mail: zfy5710@163.com

*Contributed equally

Abbreviations: MCP30, Momordica charantia protein; PTEN, phosphatase and tensin homolog; FITC, fluorescein isothiocyanate; PI, propidium iodide; EC, endometrial carcinoma; $\mathrm{MC}$, Momordica charantia; RIPs, ribosome inactivating proteins

Key words: endometrial carcinoma, AKT, cell cycle arrest, apoptosis, MCP30

\section{Introduction}

Endometrial carcinoma (EC) is one of the most common female pelvic malignancies; it develops in $\sim 142,000$ women worldwide and is responsible for $\sim 42,000$ mortalities each year (1). The 5-year survival rate is 95,67 or $16 \%$, if the cancer is diagnosed at a local, regional or distant stage, respectively (2). In China, the number of women with newly diagnosed endometrial cancer has also significantly increased annually (3).

Current treatments for EC comprise surgery, hormonal therapy, radiotherapy and chemotherapy. Young patients (age, $\leq 40$ years) who suffer from endometrial atypical hyperplasia or well-differentiated EC classified as Federation of Gynecology and Obstetrics stage IA (intramucous) may choose hormonal treatment if they decide to preserve fertility (4). However, the risk of non-response, tumor progression and recurrence remain (5). The cornerstone of treatment for EC is surgery (6); early-stage patients can achieve a satisfying outcome, but the outcomes of high-risk patients are not positive, and the patients also require adjuvant therapy, such as radiotherapy and/or chemotherapy. Radiotherapy, including vaginal brachytherapy and pelvic external beam radiotherapy, is the main method of postoperative adjuvant treatment, and can decrease the local recurrence rate (7), but no overall survival rate improvement can be found in the high-risk group (8). The cytotoxic therapies available for the treatment of advanced-stage, progressive and recurrent disease have shown limited success (9-11). Therefore, exploration of new therapeutic strategies continues to be urgently required.

Phosphate and tensin homolog (PTEN) is a tumor suppressor gene, and loss of function mutations are common and appear to be important in the pathogenesis of EC (12). Silencing of PTEN is frequently associated with advanced EC and is likely to play a critical role in promoting AKT activation (13).

Epidemiological evidence strongly suggests that diets rich in fruit and vegetables are associated with reduced risks of cancers (14). Momordica charantia (MC), often termed bitter melon, grows in tropical Asia. The fruit has been widely used as food and herbal medicine in China for centuries. However, little is known about the mechanism of the effect of MC, which 
limits the use of MC worldwide. Recently, scientists have elucidates that $\mathrm{MC}$ is capable of controlling plasma glucose, and has anti-viral, anti-fertility, immunomodulatory and antitumor effects (15-21). Our previous study successfully extracted a new protein with a molecular weight of $30 \mathrm{kDa}$ from $\mathrm{MC}$ seeds and termed it MC protein (MCP30) (22). MCP30 is a ribosome inactivating protein (RIP), which is a type of protein that can inhibit protein synthesis in cell system or cell-free system $(23,24)$.

In the present study, the effects of MCP30 on proliferation, cell cycle arrest, apoptosis and the AKT signal pathway in the human endometrial carcinoma Ishikawa $\mathrm{H}$ cell line were investigated in vitro.

\section{Materials and methods}

Reagents. RPMI-1640 medium, penicillin and streptomycin were obtained from Gibco (Thermo Fisher Scientific, Inc., Waltham, MA, USA). Fat-free milk (5\%) was obtained from Bright Dairy (Shanghai, China). Fetal bovine serum (10\%; FBS) was purchased from ZhengJiang High Technology (Tianjin, China). Tween-20, rabbit primary anti-p-AKT (dilution, 1:1,000; SAB4301414), anti-AKT (dilution, 1:1,000; SAB4500797) and anti-PTEN (dilution, 1:1,000; SAB4300337) polyclonal antibodies, horseradish peroxidase (HRP)-conjugated goat anti-rabbit IgG secondary antibody (dilution, 1:10,000; A0545) and GAPDH antibody (dilution, 1:1,000; G9545) were purchased from Sigma-Aldrich (Merck Millipore, Darmstadt, Germany). The chemiluminescent substrate for HRP was obtained from Pierce (Thermo Fisher Scientific, Inc.). MCP30 was extracted from bitter melon seeds, prepared by Xiong et al, as previously described (22).

Cell culture. The Ishikawa $\mathrm{H}$ cell line was kindly provided by the Women's Hospital, School of Medicine, Zhejiang University (Hangzhou, China), and was cultured in RPMI-1640 medium, which was supplemented with $10 \% \mathrm{FBS}, 100 \mathrm{U} / \mathrm{ml}$ penicillin and $100 \mathrm{mg} / \mathrm{ml}$ streptomycin, at $37^{\circ} \mathrm{C}$ in a fully humidified incubator containing $5 \% \mathrm{CO}_{2}$.

Cell viability assay. Cell viability in various concentrations of MCP30 (0, 8.33, 16.67, 33.33, 166.67, 333.33 and 666.67 pM; these concentrations were selected due to preliminary experiments) for 24, 48 and $72 \mathrm{~h}$ was assessed using the Cell Counting Kit-8 (CCK-8 kit; Dojindo Laboratories, Kumamoto, Japan), according to the manufacturer's protocol. In brief, $10 \mu \mathrm{l}$ of CCK-8 solution and $100 \mu \mathrm{l}$ of cell culture supernatants ( $5 \times 10^{3}$ cells, log phase) were added to each well of the 96 -well plate (Corning, Inc., Corning, NY, USA). The reaction system was incubated at $37^{\circ} \mathrm{C}$ for $1 \mathrm{~h}$. The absorbance was detected at a 450-nm wavelength using a microplate reader. Cell growth inhibition was measured using the following formula: Cell growth inhibition rate $(\%)=[1$-(value of experimental group-value of blank group)/(value of control group-value of blank group)]x 100 .

DNA fragmentation assay. The DNA of cells treated with a series of concentrations of MCP30 for $72 \mathrm{~h}$ was extracted using the selected DNA Ladder Extraction kit from Aidlab Biotechnologies (Beijing, China), according to the manufacturer's protocol. The DNA fragmentation was assayed by electrophoresis on a $1.5 \%$ agarose gel and its pattern was examined on the images obtained under ultraviolet illumination. Images were captured by Image Lab Software (Bio-Rad Laboratories, Hercules, CA, USA).

Annexin V-fluorescein isothiocyanate (FITC)/propidium iodide (PI) double staining assay. The cell apoptosis assay was performed using flow cytometry (FACSCalibur; BD Biosciences, Franklin Lakes, NJ, USA) and was detected with the Annexin V-FITC/PI Apoptosis Detection kit (BD Biosciences). Subsequent to culture of cells in 666.67 pM MCP30 for $72 \mathrm{~h}$ at $37^{\circ} \mathrm{C}$, apoptotic cells were treated with the agents of the Annexin V-FITC/PI Apoptosis Detection kit (composed of Annexin $\mathrm{V}$ binding buffer, Annexin V-FITC and PI staining solution), according to the manufacturer's protocol. In brief, cells were resuspended in $200 \mu \mathrm{l}$ Annexin $\mathrm{V}$ binding buffer and subsequently incubated with $5 \mu \mathrm{l}$ Annexin V-FITC and $10 \mu \mathrm{l}$ PI for $15 \mathrm{~min}$ in room temperature. Subsequently, $200 \mu \mathrm{l}$ Annexin $\mathrm{V}$ binding buffer was added. After $1 \mathrm{~h}$, the FITC/PI double staining reaction system was detected using flow cytometry (excitation wavelength, $488 \mathrm{~nm}$; emission wavelength, $530 \mathrm{~nm}$ ).

Cell cycle analysis. Cells were seeded in 12-well plates at a density of $4 \times 10^{4}$ cells per well in $2 \mathrm{ml}$ of complete culture medium. Subsequent to culturing with MCP30 (166.67, 333.33 or $666.67 \mathrm{pM}$ ) for 48 or $72 \mathrm{~h}$, cells were analyzed using Flow Cytometry Analysis of Cell Cycle kit (GenMed; Seisa, Plymouth, MN, USA) with a FACSCalibur Flow Cytometer (BD Biosciences) and distribution of the cell-cycle phases was determined using CellQuest Software (BD Biosciences).

Western blot analysis. Total proteins from the cells were prepared by cell lysis buffer (Applygen Technologies Inc., Beijing, China) and phenylmethylsulfonyl fluoride (Sigma-Aldrich; Merck Millipore) inactivated protease. The protein concentration was determined using the bicinchoninic acid method. Protein extracts were fractionated on $12 \%$ polyacrylamide SDS gel and then transferred to a polyvinylidene fluoride membrane. The membrane was blocked with 5\% fat-free milk in Tris-buffered saline with Tween-20 (0.1\%), followed by incubation with rabbit anti-rat primary anti-p-AKT (dilution, 1:1,000), anti-AKT (dilution, 1:1,000) and anti-PTEN (dilution, 1:1,000) polyclonal antibodies at $4^{\circ} \mathrm{C}$ for $20 \mathrm{~h}$. Subsequent to washing the membrane with TBST, the membrane was treated with HRP-conjugated goat anti-rat secondary antibody IgG-HRP (dilution, 1:10,000) for $1 \mathrm{~h}$ at room temperature via agitation. The enhanced HRP-DAB substrate solution was added to the membrane and incubated for $5 \mathrm{~min}$. Bands were visualized by chemiluminescence and exposed to X-ray. The GAPDH antibody (dilution, 1:1,000) was used as an internal control. The relative optical density (ratio to GAPDH) of each blot band was quantified by Quantity One 1-D analysis software (Bio-Rad Laboratories, Inc., Hercules, CA, USA).

Statistical analysis. Each experiment was repeated in triplicate. All data were analyzed using SPSS Statistics 19.0 (IBM Co., Armonk, NY, USA), and data were expressed as the mean \pm standard deviation. For comparisons among groups, 


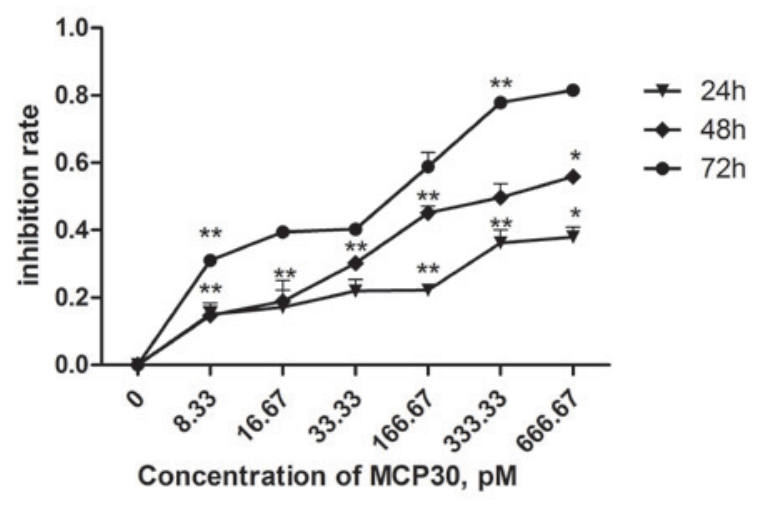

Figure 1. Inhibition rate of cells treated with various concentrations MCP30 for three periods. MCP30 significantly decreased the cell viability in a doseand time-dependent manner. All data are expressed as the percentage change in comparison with the control group, which was the cells treated with $0 \mathrm{pM}$ MCP30 and assigned a $0 \%$ inhibition rate. The data are expressed as the mean \pm standard deviation of 3 independent experiments performed in triplicate. ${ }^{*} \mathrm{P}<0.05$ and ${ }^{* *} \mathrm{P}<0.01$ compared with next lowest concentration group. MCP30, Momordica charantia protein.

independent-samples t-test and two-way analysis of variance were performed, as appropriate. If the test of homogeneity of variances was satisfied, then Tukey pairwise comparison was used for post hoc analysis. If not, Dunnet's T3 test was selected. $\mathrm{P}<0.05$ was considered to indicate a statistically significant difference.

\section{Results}

MCP30 decreased the viability of Ishikawa Hcells in a dose-and time-dependent manner. The effect of different concentrations of MCP30 on cell viability was shown in Fig. 1. MCP30 significantly decreased the cell viability in a dose- and time-dependent manner (two-way analysis of variance; time, $\mathrm{F}=89.529, \mathrm{P}<0.001$; concentration, $\mathrm{F}=56.119, \mathrm{P}<0.001)$. Following a $72 \mathrm{~h}$ incubation with $33.33 \mathrm{pM} \mathrm{MCP} 30$, the viability of the cells was reduced by $40.26 \%$ (33.33 pM group vs. control group). Additionally, 166.67 pM MCP30 reduced cell viability by $58.84 \%$ (166.67 pM group vs. control group). The half-maximal inhibitory concentration of MCP30 for $72 \mathrm{~h}$ was $\sim 62.00 \mathrm{pM}$ (data not shown). These results indicated that treatment with MCP30 decreased the viability of Ishikawa $\mathrm{H}$ cells.

MCP30 induced early apoptosis in Ishikawa $H$ cells. The results of Annexin FITC/PI staining revealed that cell viability decrease was associated with early apoptosis. The early apoptotic rates of Ishikawa H cells treated with MCP30 at $666.67 \mathrm{pM}$ reached to $16.07 \pm 0.15 \%$ following $72 \mathrm{~h}$ of treatment. By contrast, the control cells showed early apoptosis rates of only $5.08 \pm 0.19 \%$ ( $\mathrm{t}=76.589 ; \mathrm{P}<0.001$ ) (Fig. 2). Furthermore, DNA ladder was observed in cells treated with $333.33 \mathrm{pM}$ and $666.67 \mathrm{pM}$ MCP30 following $72 \mathrm{~h}$ of treatment (Fig. 2D; lanes 3 and 4), while no DNA ladder was found in the blank control and $8.33 \mathrm{pM}$ groups (lanes 1 and 2).

MCP3O affected the cell cycle distribution of Ishikawa H cells in a time-and concentration-dependent manner. Cell cycle
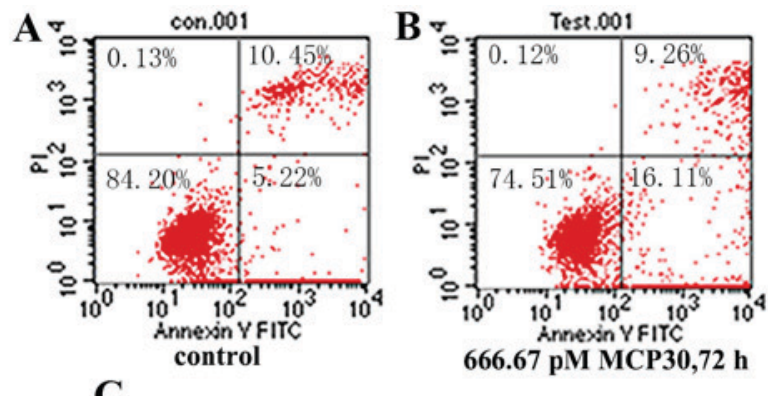

C

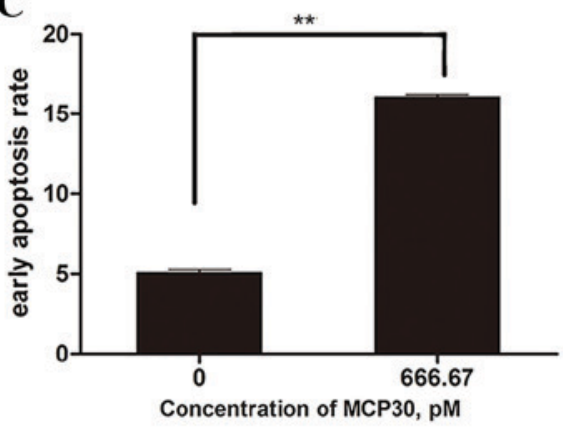

D

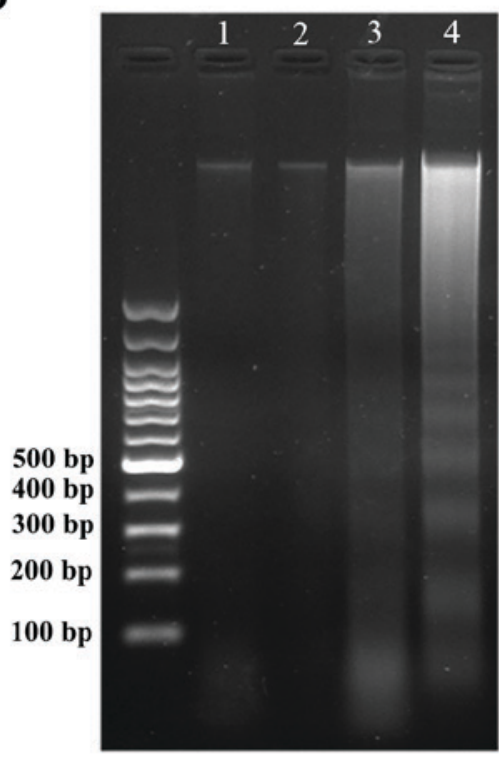

Figure 2. (A) Flow cytometry analysis of apoptotic Ishikawa $\mathrm{H}$ cells in the control group and (B) cells treated with $666.67 \mathrm{pM} \mathrm{MCP30} \mathrm{for} 72 \mathrm{~h}$. The upper left region shows necrotic cells, the upper right region shows necrotic cells and late-apoptotic cells, the lower left region shows normal live cells, and the lower right region shows early-apoptotic cells. (C) Early-apoptosis rates in the control and $666.67 \mathrm{pM}$ MCP30 groups. Data is expressed as the mean \pm standard deviation of 3 independent experiments performed in triplicate. ${ }^{* *} \mathrm{P}<0.01$. (D) DNA fragmentation assay. Lanes $1-4$ show DNA fragmentation from cells treated with 0 (lane 1), 8.33 (lane 2), 333.33 (lane 3) and $666.67 \mathrm{pM}$ (lane 4) of MCP30 for $72 \mathrm{~h}$. DNA ladder was observed in lane 3 and lane 4. MCP30, Momordica charantia protein.

analysis was performed by flow cytometry (Fig. 3). Treatment with different concentrations $(166.67,333.33$ and $666.67 \mathrm{pM})$ of MCP30 for $48 \mathrm{~h}$ resulted in the distribution of the cell phase changing so that the higher the concentration added, the lower the G0/G1-phase rate and the higher the S-phase rate $(\mathrm{G} 0 / \mathrm{G} 1$-phase rate, $\mathrm{F}=106.866, \mathrm{P}<0.001$; $\mathrm{S}$-phase rate, $\mathrm{F}=99.686, \mathrm{P}<0.001)$. The $\mathrm{G} 2 / \mathrm{M}-$ phase rate remained consistent. A similar result was obtained when the time of treatment was prolonged to $72 \mathrm{~h}$ (G0/G1-phase rate, $\mathrm{F}=169.836, \mathrm{P}<0.001$; 

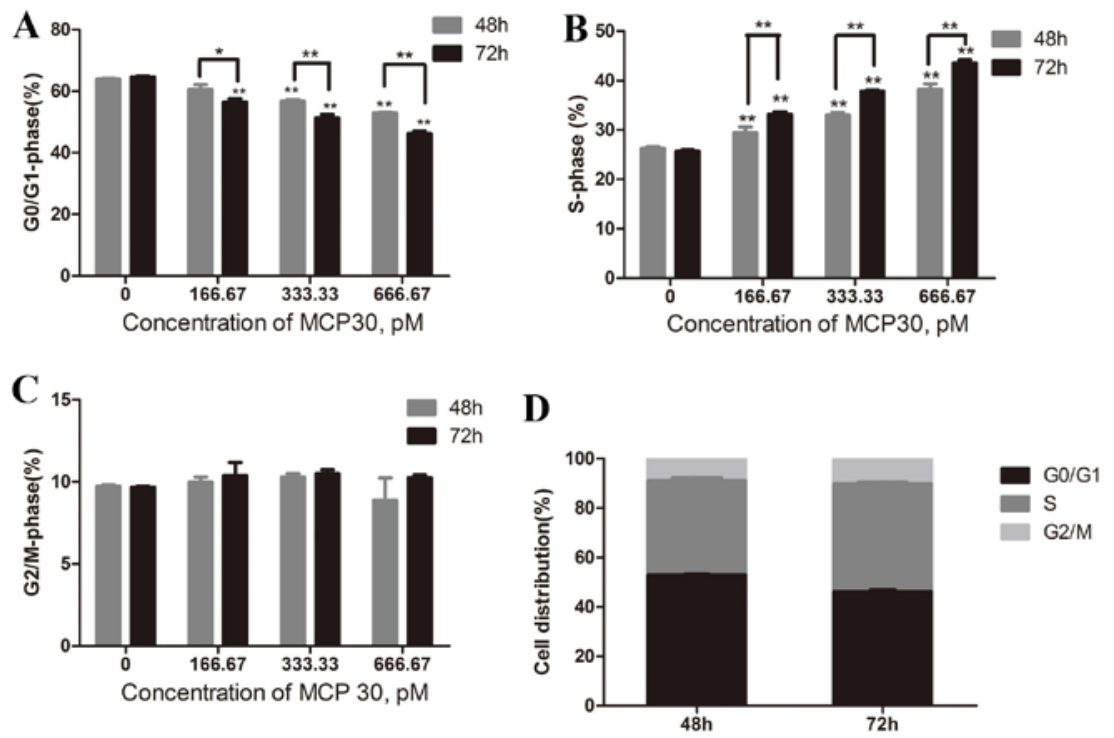

Figure 3. (A) G0/G1-phase rate of cells treated with $166.67,333.33$ and $666.67 \mathrm{pM}$ for 48 and $72 \mathrm{~h} .{ }^{* *} \mathrm{P}<0.01$, compared with the control group between different concentrations. " $\mathrm{P}<0.05,{ }^{* *} \mathrm{P}<0.01$, compared between different timepoints within the same concentration. (B) S-phase rate of cells treated with $166.67,333.33$ and $666.67 \mathrm{pM}$ for 48 and $72 \mathrm{~h} .{ }^{* *} \mathrm{P}<0.01$ compared with the control group between difference concentrations. ${ }^{*} \mathrm{P}<0.05,{ }^{* * *} \mathrm{P}<0.01$ compared between different timepoints within the same concentration. (C) G2/M-phase rate of cells treated with 166.67, 333.33 and $666.67 \mathrm{pM}$ for 48 and $72 \mathrm{~h}$. Data is expressed as the mean \pm standard deviation of 3 independent experiments performed in triplicate. (D) Cell cycle distribution of cells treated with $666.67 \mathrm{pM}$ MCP30 between 48 and $72 \mathrm{~h}$. These findings indicate that MCP30 induced S-phase arrest. MCP30, Momordica charantia protein.

\section{A}
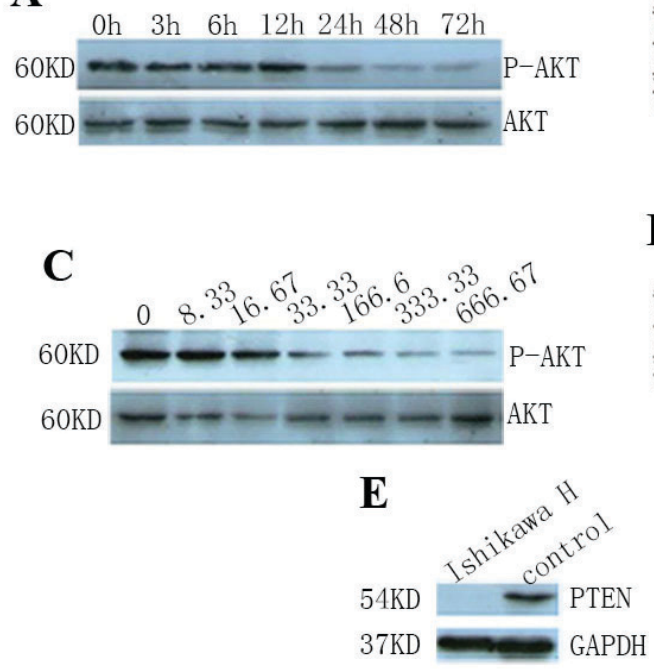

\section{B}

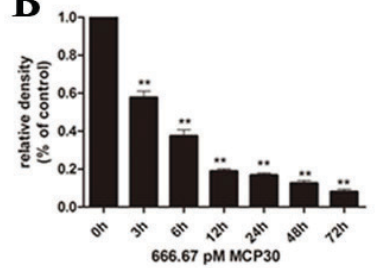

D ,

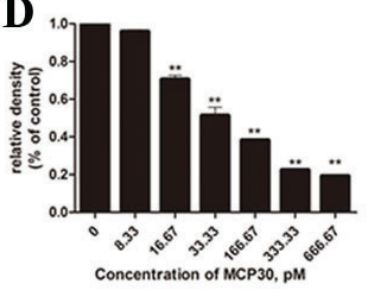

Figure 4. (A) MCP30 decreased total P-AKT expression in a time-dependent manner. (B) The relative density (P-AKT/AKT) compared to the control group at different treatment times. ${ }^{* *} \mathrm{P}<0.01$ compared with the control group. (C) MCP30 decreased total P-AKT expression in a dose-dependent manner. (D) The relative density (P-AKT/AKT) compared to the control group at various concentrations of MCP30. (E) Ishikawa H cells lost PTEN expression. P-AKT, phosphorylated AKT; PTEN, phosphate and tensin homolog; MCP30, Momordica charantia protein.

S-phase rate, $\mathrm{F}=742.190, \mathrm{P}<0.001)$. This indicated that $\mathrm{MCP} 30$ blocks Ishikawa $\mathrm{H}$ cells from progressing between the $\mathrm{S}$-phase and the G2/M-phase in a time- and concentration-dependent manner.

MCP30 induced Ishikawa $H$ cell apoptosis and S-phase arrest through the AKT signaling pathway. Finally, in order to evaluate the effect of culture time on the P-AKT expression level, 666.67 pM MCP30 was added to the cell culture system for various time points $(0,3,6,12,24,48$ and $72 \mathrm{~h})$. With increased culture time, the P-AKT level decreased $(\mathrm{F}=286.582$, $\mathrm{P}<0.001)$, but this change stopped when the time reached $12 \mathrm{~h}$, and no subsequent decrease was observed (Fig. 4A and B). Thus, it was hypothesized that $12 \mathrm{~h}$ is the best culture time for cells with MCP30. The levels of P-AKT were detected by western blot analysis following incubation with MCP30 for $72 \mathrm{~h}$ (Fig. 4C and D). MCP30 treatment decreased the levels of $\mathrm{P}-\mathrm{AKT}$ in a dose-dependent manner $(\mathrm{F}=975.799 ; \mathrm{P}<0.001)$. 
Furthermore, it was verified that Ishikawa H Cells lost PTEN expression (Fig. 4E).

\section{Discussion}

Endometrial carcinoma (EC) is a leading female pelvic malignancy, and the incidence rates of endometrial cancer are increasing in Chinese women (3). Although the mortality rate of EC has been significantly decreased due to adjuvant therapies, the increased incidence, high relapse rate and metastasis rate following treatment result in EC remaining a major clinical hurdle (25). Current treatments for EC comprise surgical resection, radiotherapy hormonal therapy and chemotherapy; for the latter, there are numerous studies investigating synthesized and natural medicinal components $(26,27)$. However, currently available and newly found drugs for the treatment of patients with advanced-stage, progressive or recurrent disease have shown limited success (9-11). Therefore, exploration of new effective drugs continues to be urgently required.

A large variety of natural compounds exhibit antitumor effects, a number of these compounds have been used as traditional herbs and are present in our daily diet (14). The plant MC, also termed bitter melon, grows in tropical Asia, where it is utilized as medicinal herb and food for centuries. Previously, studies have found that the protein extracted from MC seeds have numerous pharmacological properties, such as plasma glucose control (16), and antiviral (17), anti-fertility (18), immunomodulatory (19) and antitumor activities (28-31). However, to the best of our knowledge, studies investigating the effect of MCP30 on endometrial cancer have not yet been published. In the present study, it was found that MCP30 exhibited potent cytotoxic activity in EC cells.

EC is classified into two types (types 1 and 2), with the most common lesions (type 1) typically being hormone-sensitive (6). Therefore, the Ishikawa $H$ cell line, a type of estrogen-dependent endometrial cancer cell line (32), was chosen. The CCK-8 results showed that MCP30 inhibited cell viability in a dose- and time-dependent manner. In the cell cycle experiment, it appeared that MCP30 may induce S-phase arrest in EC cells. In addition, previous studies have suggested that MCP30 is a type I RIP (33). At present, it is acknowledged that RIPs are classified into two major types (34). Type I RIPs consist of only a single rRNA-cleaving domain and have a molecular weight $\sim 30 \mathrm{kDa}$, while type II RIPs have another B chain, which make them manifest marked cytotoxicity, such as ricin (35). Proteins that are classed as RIPs are mainly present in plants (36), and have the ability to inhibit protein synthesis in a cell system or cell-free system $(24,37)$. RIPs have been shown to exhibit RNA N-glycosidase activity and to modify two nucleoside residues, G4323 and A4324, in $28 \mathrm{~S}$ rRNA of the eukaryotic $60 \mathrm{~S}$ ribosomal subunit, resulting in the failure of combination with elongation factor and making RIPs protein synthesis inhibitors (23). It is well known that $\mathrm{S}$-phase is a period for DNA duplication and the synthesis of histones and other necessary proteins (38). If either of the synthesis processes is interrupted, cells arrest in S-phase. Wang et al reported that MCP30 has DNase-like enzymatic activity and can nick closed circular Pet-32a(+) plasmid DNA to open circular conformation, making plasmid DNA exhibit a linear formation (39). Our previous study has also revealed that
MCP30 has potential histone deacetylase inhibitor function that selectively increases histone acetylation in neoplastic prostate cell lines (22). Zhang et al found that low concentrations of trichosanthin, another type 1 RIP that shares 59\% sequence similarity with MCP30, induces apoptosis and S-phase cell cycle arrest in two laryngeal cancer cell lines (40). Additional studies investigating the effect of MCP30 on certain S cell cycle regulating proteins, such as cyclin A, checkpoint kinase (Chk) 1, Chk2 and p53, are required.

It was revealed in the present study that MCP30 exhibited cell cycle arrest and apoptosis-inducing activities. Flow cytometry analysis using Annexin V/PI showed that MCP30 dose-dependently induces early apoptosis in the Ishikawa $\mathrm{H}$ cell line. Subsequently, typical DNA fragmentation ladders were found subsequent to treatment. The AKT pathway has been widely studied and plays an important role in cellular growth and survival. This pathway is commonly considered to be an important target for cancer chemotherapy (41). AKT has been reported as overexpressed in numerous malignancies $(42,43)$, including EC (44). PTEN, a tumor suppressor gene, is the major negative regulator of the AKT pathway (45). Loss of function mutations of PTEN are common and appear to be important in the pathogenesis of type I EC (12). In the present study, PTEN loss was also verified in the Ishikawa $\mathrm{H}$ cell line, which is consistent with previous findings (32). There was an apparent negative associated between MCP30 concentrations and the P-AKT level (Fig. 4B). Previously, Somasagara et al found MCP30 effectively decreased AKT phosphorylation and viability of gemcitabine-resistant pancreatic cancer cells (46). Overall, in the present study MCP30 showed cytotoxicity to EC cells, partially through decreasing activation of the AKT pathway.

Previously, extensive efforts in developing inhibitors of the AKT pathway as therapeutic agents to treat cancers in which the AKT pathway is hyperactivated have been thwarted by unacceptable toxicity or poor pharmacokinetics (47-52). MCP30 as a type I RIP, devoid of a cell-binding B chain, have less cytotoxic effects than the majority of type II RIPs (53). These observations suggested that MCP30 has good potential as a cytotoxic agent against EC cells and warrants additional investigation.

\section{References}

1. Amant F, Moerman P, Neven P, Timmerman D, Van Limbergen E and Vergote I: Endometrial cancer. Lancet 366: 491-505, 2005.

2. American Cancer Society. Cancer Facts \& Figures 2013. American Cancer Society Inc., Atlanta, GA, 2013.

3. Li X, Zheng S, Chen S, Qin F, Lau S and Chen Q: Trends in gynaecological cancers in the largest obstetrics and gynaecology hospital in China from 2003 to 2013. Tumour Biol 36: 4961-4966, 2015.

4. Laurelli G, Di Vagno G, Scaffa C, Losito S, Del Giudice M and Greggi S: Conservative treatment of early endometrial cancer: Preliminary results of a pilot study. Gynecol Oncol 120: 43-46, 2011.

5. Wang CJ, Chao A, Yang LY, Hsueh S, Huang YT, Chou HH, Chang TC and Lai CH: Fertility-preserving treatment in young women with endometrial adenocarcinoma: A long-term cohort study. Int J Gynecol Cancer 24: 718-728, 2014.

6. Amant F, Moerman P, Neven P, Timmerman D, Van Limbergen E and Vergote I: Endometrial cancer. Lancet 366: 491-505, 2005.

7. Nout RA, Smit VT, Putter H, Jürgenliemk-Schulz IM, Jobsen JJ, Lutgens LC, van der Steen-Banasik EM, Mens JW, Slot A, Kroese MC, et al: Vaginal brachytherapy versus pelvic external beam radiotherapy for patients with endometrial cancer of high-intermediate risk (PORTEC-2): An open-label, non-inferiority, randomised trial. Lancet 375: 816-823, 2010. 
8. ASTEC/EN.5 Study Group, Blake P, Swart AM, Orton J, Kitchener H, Whelan T, Lukka H, Eisenhauer E, Bacon M, Tu D, et al: Adjuvant external beam radiotherapy in the treatment of endometrial cancer (MRC ASTEC and NCIC CTG EN.5 randomised trials): Pooled trial results, systematic review, and meta-analysis. Lancet 373: 137-146, 2009.

9. Humber CE, Tierney JF, Symonds RP, Collingwood M, Kirwan J, Williams C and Green JA: Chemotherapy for advanced, recurrent or metastatic endometrial cancer: A systematic review of Cochrane collaboration. Ann Oncol 18: 409-420, 2007.

10. Amadio G, Masciullo V, Stefano L and Scambia G: An update on the pharmacotherapy for endometrial cancer. Expert Opin Pharmacother 14: 2501-2509, 2013.

11. Homesley HD, Filiaci V, Gibbons SK, Long HJ, Cella D, Spirtos NM, Morris RT, DeGeest K, Lee R and Montag A: A randomized phase III trial in advanced endometrial carcinoma of surgery and volume directed radiation followed by cisplatin and doxorubicin with or without paclitaxel: A gynecologic oncology group study. Gynecol Oncol 112: 543-552, 2009.

12. Mutter GL, Lin MC, Fitzgerald JT, Kum JB, Baak JP, Lees JA, Weng LP and Eng C: Altered PTEN expression as a diagnostic marker for the earliest endometrial precancers. J Natl Cancer Inst 92: 924-930, 2000

13. Terakawa N, Kanamori Y and Yoshida S: Loss of PTEN expression followed by Akt phosphorylation is a poor prognostic factor for patients with endometrial cancer. Endocr Relat Cancer 10: 203-208, 2003

14. Cai Y, Luo Q, Sun M and Corke H: Antioxidant activity and phenolic compounds of 112 traditional Chinese medicinal plants associated with anticancer. Life Sci 74: 2157-2184, 2004.

15. Grover JK and Yadav SP: Pharmacological actions and potential uses of Momordica charantia: A review. J Ethnopharmacol 93 123-132, 2004

16. Tan MJ, Ye JM, Turner N, Hohnen-Behrens C, Ke CQ, Tang CP, Chen T, Weiss HC, Gesing ER, Rowland A, et al: Antidiabetic activities of triterpenoids isolated from bitter melon associated with activation of the AMPK pathway. Chem Biol 15: 263-273, 2008.

17. Lee-Huang S, Huang PL, Nara PL, Chen HC, Kung HF, Huang P, Huang HI and Huang PL: MAP 30: A new inhibitor of HIV-1 infection and replication. FEBS Lett 272: 12-18, 1990.

18. Adewale OO, Oduyemi OI and Ayokunle O: Oral administration of leaf extracts of Momordica charantia affect reproductive hormones of adult female Wistar rats. Asian Pac J Trop Biomed 4 (Suppl 1): S521-S524, 2014

19. Deng YY, Yi Y, Zhang LF, Zhang RF, Zhang Y, Wei ZC, Tang XJ and Zhang MW: Immunomodulatory activity and partial characterisation of polysaccharides from Momordica charantia. Molecules 19: 13432-13447, 2014.

20. Fan JM, Luo J, Xu J, Zhu S, Zhang Q, Gao DF, Xu YB and Zhang GP: Effects of recombinant MAP30 on cell proliferation and apoptosis of human colorectal carcinoma LoVo cells. Mol Biotechnol 39: 79-86, 2008.

21. Zhang CZ, Fang EF, Zhang HT, Liu LL and Yun JP: Momordica Charantia lectin exhibits antitumor activity towards hepatocellular carcinoma. Invest New Drugs 33: 1-11, 2015.

22. Xiong SD, Yu K, Liu XH, Yin LH, Kirschenbaum A, Yao S, Narla G, DiFeo A, Wu JB, Yuan Y, et al: Ribosome-inactivating proteins isolated from dietary bitter melon induce apoptosis and inhibit histone deacetylase-1 selectively in premalignant and malignant prostate cancer cells. Int J Cancer 125: 774-782, 2009.

23. Endo Y, Mitsui K, Motizuki M and Tsurugi K: The mechanism of action of ricin and related toxic lectins on eukaryotic ribosomes. The site and the characteristics of the modification in $28 \mathrm{~S}$ ribosomal RNA caused by the toxins. J Biol Chem 262 : 5908-5912, 1987.

24. Olsnes S and Pihl A: Treatment of abrin and ricin with -mercaptoethanol opposite effects on their toxicity in mice and their ability to inhibit protein synthesis in a cell-free system. FEBS Lett 28: 48-50, 1972.

25. Mitsuhashi A, Sato Y, Kiyokawa T, Koshizaka M, Hanaoka H and Shozu M: Phase II study of medroxyprogesterone acetate plus metformin as a fertility-sparing treatment for atypical endometrial hyperplasia and endometrial cancer. Ann Oncol 27: 262-266, 2016.

26. Fong P and Meng LR: Effect of mTOR inhibitors in nude mice with endometrial carcinoma and variable PTEN expression status. Med Sci Monit Basic Res 20: 146-152, 2014.

27. Feng W, Yang CX, Zhang L, Fang Y and Yan M: Curcumin promotes the apoptosis of human endometrial carcinoma cells by downregulating the expression of androgen receptor through Wnt signal pathway. Eur J Gynaecol Oncol 35: 718-723, 2014.
28. Ray RB, Raychoudhuri A, Steele R and Nerurkar P: Bitter melon (Momordica charantia) extract inhibits breast cancer cell proliferation by modulating cell cycle regulatory genes and promotes apoptosis. Cancer Res 70: 1925-1931, 2010.

29. Pitchakarn P, Ogawa K, Suzuki S, Takahashi S, Asamoto M, Chewonarin T, Limtrakul P and Shirai T: Momordica charantia leaf extract suppresses rat prostate cancer progression in vitro and in vivo. Cancer Sci 101: 2234-2240, 2010.

30. Chipps ES, Jayini R, Ando S, Protzman AD, Muhi MZ, Mottaleb MA, Malkawi A and Islam MR: Cytotoxicity analysis of active components in bitter melon (Momordica charantia) seed extracts using human embryonic kidney and colon tumor cells. Nat Prod Commun 7: 1203-1208, 2012.

31. Fang EF, Zhang CZ, Wong JH, Shen JY, Li CH and Ng TB: The MAP30 protein from bitter gourd (Momordica charantia) seeds promotes apoptosis in liver cancer cells in vitro and in vivo. Cancer Lett 324: 66-74, 2012.

32. Albitar L, Pickett G, Morgan M, Davies S and Leslie KK: Models representing type I and type II human endometrial cancers: Ishikawa $\mathrm{H}$ and $\mathrm{Hec50co}$ cells. Gynecol Oncol 106 52-64, 2007.

33. Yeung HW, Li WW, Feng Z, Barbieri L and Stirpe F: Trichosanthin, alpha-momorcharin and beta-momorcharin: Identity of abortifacient and ribosome-inactivating proteins. Int J Pept Protein Res 31: 265-268, 1988.

34. Walsh MJ, Dodd JE and Hautbergue GM: Ribosome-inactivating proteins: Potent poisons and molecular tools. Virulence 4: 774-784, 2013.

35. Olsnes S and Pihl A: Different biological properties of the two constituent peptide chains of ricin, a toxic protein inhibiting protein synthesis. Biochemistry 12: 3121-3126, 1973.

36. Stirpe F, Barbieri L, Battelli MG, Soria M and Lappi DA: Ribosome-inactivating proteins from plants: Present status and future prospects. Biotechnology (NY) 10: 405-412, 1992.

37. de Virgilio M, Lombardi A, Caliandro R and Fabbrini MS: Ribosome-inactivating proteins: From plant defense to tumor attack. Toxins (Basel) 2: 2699-2737, 2010.

38. Hartwell LH and Weinert TA: Checkpoints: Controls that ensure the order of cell cycle events. Science 246: 629-634, 1989.

39. Wang S, Zheng Y, Yan J, Zhu Z, Wu Z and Ding Y: Alpha-momorcharin: A ribosome-inactivating protein from Momordica charantia, possessing DNA cleavage properties. Protein Pept Lett 20: 1257-1263, 2013

40. Zhang D, Chen B, Zhou J, Zhou L, Li Q, Liu F, Chou KY, Tao L and Lu LM: Low concentrations of trichosanthin induce apoptosis and cell cycle arrest via c-Jun N-terminal protein kinase/mitogen-activated protein kinase activation. Mol Med Rep 11: 349-356, 2015.

41. Manning BD and Cantley LC: AKT/PKB signaling: Navigating downstream. Cell 129: 1261-1274, 2007.

42. Banerji S, Cibulskis K, Rangel-Escareno C, Brown KK, Carter SL, Frederick AM, Lawrence MS, Sivachenko AY, Sougnez C, Zou L, et al: Sequence analysis of mutations and translocations across breast cancer subtypes. Nature 486: 405-409, 2012

43. Vivanco I and Sawyers CL: The phosphatidylinositol 3-Kinase AKT pathway in human cancer. Nat Rev Cancer 2: 489-501, 2002.

44. Oda K, Stokoe D, Taketani Y and McCormick F: High frequency of coexistent mutations of PIK3CA and PTEN genes in endometrial carcinoma. Cancer Res 65: 10669-10673, 2005.

45. Stambolic V, Suzuki A, de la Pompa JL, Brothers GM, Mirtsos C, Sasaki T, Ruland J, Penninger JM, Siderovski DP and Mak TW: Negative regulation of $\mathrm{PKB} / \mathrm{Akt}$-dependent cell survival by the tumor suppressor PTEN. Cell 95: 29-39, 1998.

46. Somasagara RR, Deep G, Shrotriya S, Patel M, Agarwal C and Agarwal R: Bitter melon juice targets molecular mechanisms underlying gemcitabine resistance in pancreatic cancer cells. Int J Oncol 46: 1849-1857, 2015.

47. Matulonis U, Vergote I, Backes F, Martin LP, McMeekin S, Birrer M, Campana F, Xu Y, Egile C and Ghamande S: Phase II study of the PI3K inhibitor pilaralisib (SAR245408; XL147) in patients with advanced or recurrent endometrial carcinoma. Gynecol Oncol 136: 246-253, 2015.

48. Jimeno A, Bauman JE, Weissman C, Adkins D, Schnadig I, Beauregard P, Bowles DW, Spira A, Levy B, Seetharamu N, et al: A randomized, phase 2 trial of docetaxel with or without PX-866, an irreversible oral phosphatidylinositol 3-kinase inhibitor, in patients with relapsed or metastatic head and neck squamous cell cancer. Oral Oncol 51: 383-388, 2015. 
49. Konopleva MY, Walter RB, Faderl SH, Jabbour EJ, Zeng Z, Borthakur G, Huang X, Kadia TM, Ruvolo PP, Feliu JB, et al: Preclinical and early clinical evaluation of the oral AKT inhibitor, MK-2206, for the treatment of acute myelogenous leukemia. Clin Cancer Res 20: 2226-2235, 2014.

50. Massarelli E, Lin H, Ginsberg LE, Tran HT, Lee JJ, Canales JR, Williams MD, Blumenschein GR Jr, Lu C, Heymach JV, et al: Phase II trial of everolimus and erlotinib in patients with platinum-resistant recurrent and/or metastatic head and neck squamous cell carcinoma. Ann Oncol 26: 1476-1480, 2015.

51. Oza AM, Pignata S, Poveda A, McCormack M, Clamp A Schwartz B, Cheng J, Li X, Campbell K, Dodion P and Haluska FG: Randomized phase II trial of ridaforolimus in advanced endometrial carcinoma. J Clin Oncol 33: 3576-3582, 2015 .
52. Bauman JE, Arias-Pulido H, Lee SJ, Fekrazad MH, Ozawa H, Fertig E, Howard J, Bishop J, Wang H, Olson GT, et al: A phase II study of temsirolimus and erlotinib in patients with recurrent and/or metastatic, platinum-refractory head and neck squamous cell carcinoma. Oral Oncol 49: 461-467, 2013.

53. Stirpe F: Ribosome-inactivating proteins: From toxins to useful proteins. Toxicon 67: 12-16, 2013. 